\title{
Efficient synthesis of pyrazolopyridines containing a chromane backbone through domino reaction
}

\author{
Razieh Navari ${ }^{1}$, Saeed Balalaie ${ }^{* 1,2}$, Saber Mehrparvar ${ }^{1}$, Fatemeh Darvish ${ }^{1}$, \\ Frank Rominger ${ }^{3}$, Fatima Hamdan ${ }^{1}$ and Sattar Mirzaie ${ }^{1}$
}

\author{
Full Research Paper \\ Address: \\ ${ }^{1}$ Peptide Chemistry Research Center, K. N. Toosi University of \\ Technology, P. O. Box 15875-4416, Tehran, Iran, Tel: \\ +98-21-23064226, Fax: +98-21-22889403, ${ }^{2}$ Medical Biology \\ Research Center, Kermanshah University of Medical Sciences, \\ Kermanshah, Iran and ${ }^{3}$ Organisch-Chemisches Institut der \\ Universitaet Heidelberg, Im Neuenheimer Feld 270, D-69120 \\ Heidelberg, Germany \\ Email: \\ Saeed Balalaie* - balalaie@kntu.ac.ir \\ * Corresponding author \\ Keywords: \\ chromane; domino reaction; fused heterocyclic skeletons; \\ pyrazolopyridines
}

\author{
Beilstein J. Org. Chem. 2019, 15, 874-880. \\ doi:10.3762/bjoc. 15.85 \\ Received: 07 February 2019 \\ Accepted: 29 March 2019 \\ Published: 11 April 2019 \\ Associate Editor: T. J. J. Müller \\ (c) 2019 Navari et al.; licensee Beilstein-Institut. \\ License and terms: see end of document.
}

\section{Abstract}

An efficient approach for the synthesis of pyrazolopyridines containing the aminochromane motif through a base-catalyzed cyclization reaction is reported. The synthesis was carried out through a three-component reaction of (arylhydrazono)methyl- $4 H$-chromen4-one, malononitrile, primary amines in the presence of $\mathrm{Et}_{3} \mathrm{~N}$ at room temperature. However, carrying out the reaction under the same conditions without base led to a fused chromanyl-cyanopyridine. High selectivity, high atom economy, and good to high yields in addition to mild reaction conditions are the advantages of this approach.

\section{Introduction}

The synthesis of new fused heterocyclic backbones has always been a major challenge in the field of organic synthesis [1-3] Multicomponent reactions (MCRs) and domino reactions are known as efficient synthetic approaches for the synthesis of complex molecules [4-6]. Domino reactions have been defined by Tietze and were applied for the synthesis of complicated scaffolds [7-9]. The selection of a suitable starting material and designing a post-transformational reaction is a key point for the synthesis of complex molecules through the designing of domino reactions [10].
Chromone derivatives have been found to exhibit a broad range of biological activities [11-13]. 3-Formylchromone was used as a suitable starting material for the construction of various heterocyclic skeletons [14-17].

Pyrazolopyridines are a promising class of heterocyclic compounds which inhibits cyclin-dependent protein kinase-2 (cdk2 ), cyclin-dependent protein kinase-5 (cdk-5), and phosphatidylinositol 3-kinase (PI3-K) [18-21]. Thus, these compounds have a high potential for the treatment of several neuro- 
logical diseases. Some examples of pyrazolopyridine derivatives are anxiolytic drugs such as tracazolate, cartazolate, and etazolate [22]. Other pyrazolopyridine-containing bioactive compounds include a GSK-3 inhibitor [23] and BAY 41-2272, $[24,25]$ and could be used as cardiovascular therapeutic agents (Figure 1). Moreover, pyrazolopyridine derivatives also have industrial importance as fluorophores and luminophores in organic light emitting diodes [26,27].

The synthesis of pyrazolopyridines has been reported in several different multistep manners [28-36]. However, some of the reported methods have several limitations such as long reaction time, low yields, boring workup procedures, and several side reactions with less selectivity of the process. Due to the extended biological activities of pyrazolopyridines, finding a suitable approach for the synthesis of these compounds is a synthetic challenge in organic synthesis. In continuation of our research work to construct fused heterocyclic skeletons [37-40], we describe the synthesis of pyrazolopyridines $\mathbf{4 a}-\mathbf{m}$ containing a chromone moiety (Scheme 1). The synthetic approach was based on a domino reaction of (arylhydrazono)methyl-4Hchromen-4-one 1a-g, primary amines $\mathbf{2 a - c}$, and malononitrile (3) in the presence of triethylamine in ethanol at room temperature.

\section{Results and Discussion}

In the beginning, 3-formylchromone was prepared based on a known method [41]. Then, we focused our initial study on the preparation of the (arylhydrazono)methyl-4H-chromen-4-one via the reaction of 3-formylchromone and phenylhydrazine $[42,43]$. Subjecting (arylhydrazono)methyl-4H-chromen-4-one (1a), benzylamine (2a), and malononitrile (3) in the presence of

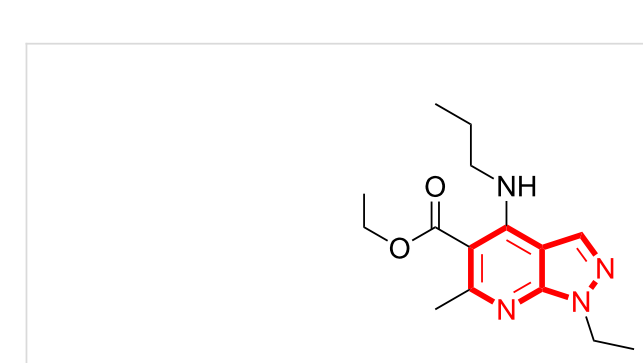

tracazolate<smiles>CCCCNc1c(C(=O)OCC)c(C)nc2c1cnn2CC</smiles>

carcazolate<smiles>CCOC(=O)c1cnc2c(cnn2CC)c1NN=C(C)C</smiles>

etazolate<smiles>O=C(Nc1n[nH]c2nc(-c3ccc(O)cc3)c(Br)cc12)C1CC1</smiles>

GSK-3 inhibitor<smiles>Cc1nc(-c2nn(Cc3ccccc3F)c3ncccc23)ncc1C1CC1</smiles>

BAY 41-2272

Figure 1: Selected examples of bioactive molecules based on the pyrazolopyridine framework.<smiles>[R]NC1Oc2ccc([X])cc2-c2nc3nn([R])c(N)c3cc2C1N[R10]</smiles> 
$40 \%$ triethylamine was stirred at room temperature in ethanol. Compound $\mathbf{4 a}$ was precipitated and filtered. After confirmation of the structure, we tried to find a suitable base and solvent for the model reaction. The results are summarized in Table 1.

Table 1: Optimization of solvent and base for the synthesis of $4 a$ as a model reaction.

\begin{tabular}{llll} 
Entry & Base & Solvent & Yield $^{\mathrm{a}}(\%)$ \\
\hline 1 & $\mathrm{Et}_{3} \mathbf{N} 40 \%$ & $\mathrm{EtOH}$ & $\mathbf{6 5}$ \\
2 & $\mathrm{DBU} 40 \%$ & $\mathrm{EtOH}$ & 61 \\
3 & $\mathrm{DIPEA} \mathrm{40 \%}$ & $\mathrm{EtOH}$ & 60 \\
4 & $\mathrm{Et}_{3} \mathrm{~N} \mathrm{40 \%}$ & $\mathrm{DCM}$ & 12 \\
5 & $\mathrm{Et}_{3} \mathrm{~N} \mathrm{40 \%}$ & $\mathrm{MeCN}$ & 35 \\
6 & $\mathrm{Et}_{3} \mathrm{~N} \mathrm{40 \%}$ & $\mathrm{MeOH}$ & 63 \\
\hline
\end{tabular}

aThe reported yields are the related amount of pure precipitate that did not require any further purification.

The reactions were studied in the presence of $10,20,30 \%$ triethylamine as a base in ethanol and the yields were formed 25 , $38,58 \%$, respectively (entries $1-3$, Table 1 ). After changing the ratio of triethylamine to $40 \%$, the yield of pure product was increased to $65 \%$ in ethanol. The yield of the reaction in the presence of DBU and diisopropylethylamine (DIPEA) as a base were 61 and $60 \%$, respectively. This means that the type of base does not play an effective role in this reaction. The effect of different solvents (EtOH, $\mathrm{MeOH}, \mathrm{MeCN}$, and $\mathrm{DCM}$ ) was investigated on the progress of the reaction. As shown in Table 1, carrying out the reaction in $\mathrm{EtOH}$ was found the best choice due to the better yield (65\%). Based on this data, the optimized reaction conditions were achieved using $40 \%$ of $\mathrm{Et}_{3} \mathrm{~N}$ in ethanol at room temperature. The use of a protic solvent seems to be essential for the progress of the reaction and may related to the dipole moment and also the hydrogen-bonding ability of protic solvents.

The spectroscopic data confirmed the formation of $4 \mathbf{a}$. The $\mathrm{X}$-ray crystallographic data of compound 4 a confirmed the structure of the product (Figure 2). Meanwhile, via hydrogen bridges and the solvent molecules (water and ethanol) the molecules build pairs with $\pi-\pi$ stacking of the aromatic systems.

To examine the scope and generality of our reaction, other (arylhydrazono)methyl-4H-chromen-4-ones were synthesized and their reaction with different primary amines and malononitrile were examined and compounds $\mathbf{4 a}-\mathbf{m}$ were formed. The results are summarized in Figure 3. In another experiment, the model reaction of (arylhydrazono)methyl- $4 H$-chromen-4-one (1a), phenylethylamine (2b), and malononitrile (3) were investigated in ethanol at room temperature. The formed precipitate was collected as the sole product and the spectroscopic data were investigated and showed that the product is identified as the fused heterocyclic pyridinochromane 5a. This confirmed that the final cyclization needs basic reaction conditions.

The synthesized (arylhydrazono)methyl-4H-chromen-4-ones 1a-g have several electron-deficient centers such as at C-2, C-4
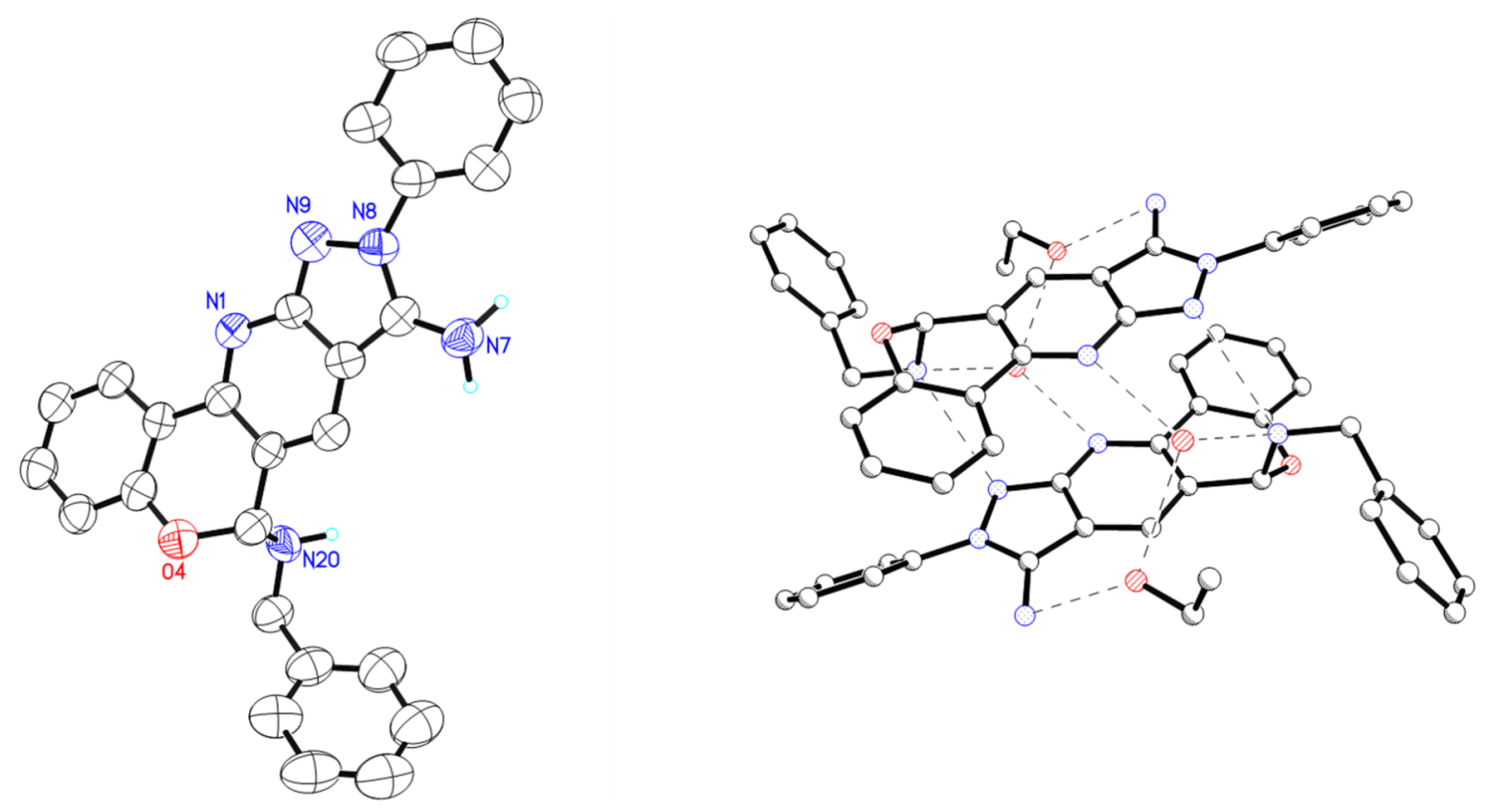

Figure 2: ORTEP Structure of compound $4 \mathrm{a}$ and intermolecular hydrogen bonding; the ellipsoid probability level of each ORTEP diagram is $50 \%$. 
<smiles>Nc1c2cc3c(nc2nn1-c1ccccc1)-c1ccccc1OC3NCc1ccccc1</smiles>

$4 a$ $65 \%$<smiles>Nc1c2cc3c(nc2nn1-c1ccccc1)-c1cc(F)ccc1OC3NCCc1ccccc1</smiles>

4 e<smiles>Nc1c2cc3c(nc2nn1-c1ccc(F)cc1)-c1ccccc1OC3NCc1ccccc1</smiles>

$4 \mathbf{i}$

$62 \%$<smiles>Nc1c2cc3c(nc2nn1-c1ccccc1)-c1cc(Cl)ccc1OC3NCc1ccccc1</smiles>

4b

$69 \%$<smiles>Nc1c2cc3c(nc2nn1-c1ccccc1)-c1ccccc1OC3NCCc1ccccc1</smiles>

$4 c$

$64 \%$<smiles>Nc1c2cc3c(nc2nn1-c1ccccc1)-c1ccccc1OC3NC1CCCCC1</smiles>

4d

$61 \%$<smiles>Nc1c2cc3c(nc2nn1-c1ccccc1)-c1cc(F)ccc1OC3NCc1ccccc1</smiles>

$4 \mathbf{4}$

$67 \%$<smiles>Nc1c2cc3c(nc2nn1-c1ccccc1)-c1ccccc1OC3NCc1ccco1</smiles><smiles>Nc1c2cc3c(nc2nn1-c1ccccc1)-c1cc(Br)ccc1OC3NCc1ccccc1</smiles>

4g

$66 \%$<smiles>COc1ccc(-n2nc3nc4c(cc3c2N)C(NCc2ccccc2)Oc2ccccc2-4)cc1</smiles>

4k

$77 \%$<smiles>NC1=C2C=C3c4ccccc4C(NC4CCCCC4)N3N=C2c2ccccc2O1</smiles>

4h

$60 \%$<smiles>COc1ccc(-n2nc3nc4c(cc3c2N)C(NC2CCCCC2)Oc2ccccc2-4)cc1</smiles>

41

$\mathbf{4 j}$
$63 \%$ $\mathrm{COOH}$<smiles>Cc1ccc(-n2nc3nc4c(cc3c2N)C(NCc2ccccc2)Oc2ccccc2-4)cc1</smiles>

$80 \%$

$4 \mathrm{~m}$

$40 \%$

Figure 3: Structures of synthesized pyrazolopyridines $\mathbf{4 a}-\mathbf{m}$. Reaction conditions: 3-formylchromone derivatives (1 mmol), primary amine (1.2 mmol), malononitile $(1.2 \mathrm{mmol})$, $\mathrm{Et}_{3} \mathrm{~N}(40 \mathrm{mmol} \%)$ in $3 \mathrm{~mL}$ ethanol at room temperature for $8-12 \mathrm{~h}$.

and $\mathrm{C}=\mathrm{N}$ and are susceptible to different intramolecular and intermolecular ring formations.

It seems that a proposed mechanism could proceed initially through (arylhydrazono)methyl- $4 H$-chromen-4-one as a suitable Michael acceptor that can react with benzylamine or any primary amine to produce the intermediate A. There is a conju- gated system in intermediate A that allows malononitrile to attack through Michael addition and produces the intermediate B (Scheme 2). Due to the presence of acidic hydrogen in intermediate $\mathrm{B}$, it is possible to form chromonyl-malononitrile conjugated system $\mathrm{C}$ and to eliminate the phenylhydrazine. Intermediate $\mathrm{C}$ is a highly potent Michael acceptor that may allow the addition of hydrazine to the nitrile group resulting in 
intermediate D that after elimination of water led to intermediate $\mathrm{E}$ and this intermediate in the presence of a base can be converted to the $\mathbf{4 a}-\mathbf{m}$ after tautomerization. The compounds $\mathbf{5 a}-\mathbf{d}$ were formed through the same procedure without the base and after air oxidation. To confirm the mechanism, the reaction was done under inert atmosphere and the products $5 \mathbf{a}-\mathbf{d}$ were not formed. The reaction mechanism is shown in Scheme 2.
The chemical structures of the products $\mathbf{5 a}-\mathbf{d}$ are shown in Figure 4.

Usually, to activate the nitrile group for cyclization reaction, the existence of Lewis acid, the addition of organolithium reagents or metal hexamethylenedisalazane is necessary. However, in this approach, the nucleophilic addition on the nitrile group and<smiles>N#Cc1cc2c(nc1N=Nc1ccccc1)-c1ccccc1OC2NCc1ccccc1</smiles>

$5 a$

$33 \%$<smiles>N#Cc1cc2c(nc1N=Nc1ccccc1)-c1ccccc1OC2NCCc1ccccc1</smiles>

5b

$35 \%$<smiles>COc1ccc(N=Nc2nc3c(cc2C#N)C(NCCc2ccccc2)Oc2ccccc2-3)cc1</smiles>

$5 c$

$40 \%$<smiles>N#Cc1cc2c(nc1N=Nc1ccccc1)-c1ccccc1OC2Nc1ccc(Cl)cc1</smiles>

$5 d$

Figure 4: Structures of synthesized compounds $\mathbf{5 a - d .}$<smiles></smiles>

A<smiles></smiles>

$[1,5]-\mathrm{H}$ shift<smiles>[R]NC1Oc2ccccc2-c2nc3nn([R1])c(N)c3cc21</smiles><smiles>CCC(CC)(NNF)[C@H](C)C#N</smiles>

B

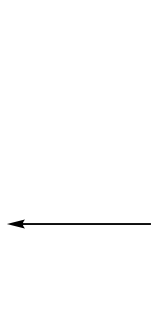<smiles>[R]NC1Oc2ccccc2-c2nc(N[R]([R])[H])c(C#N)cc21</smiles>

E aromatization<smiles>[R]NNCCC[C@H](C)/C(C#N)=C/c1coc2ccccc2c1=O</smiles>

C

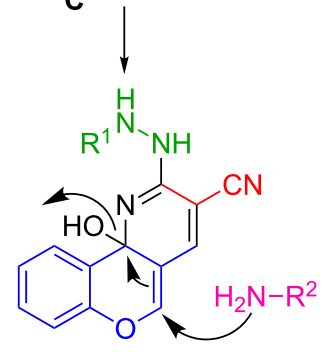

D

$\downarrow \begin{gathered}\text { air } \\ \text { oxidation }\end{gathered}$<smiles>[R1]N=Nc1nc2c(cc1C#N)C(N[R])Oc1ccccc1-2</smiles>

Scheme 2: The proposed mechanism for the synthesis of pyrazolopyridines derivatives $4 \mathbf{a}-\mathbf{m}$ and $\mathbf{5 a}-\mathbf{d}$. 
the cyclization was achieved without the addition of a catalyst [44]. This reaction possesses a highly atom economical character and requires only triethylamine $(40 \mathrm{~mol} \%)$ as a base in EtOH and provides fused heterocyclic backbones with high selectivity.

\section{Conclusion}

In conclusion, we have successfully established an efficient route toward the synthesis of a diverse array of fused heterocyclic skeletons through a domino reaction. We showed an interesting behavior of the base for the cyclization reaction and provided access to fused heterocycles pyrazolopyridines containing chromane. The same reaction without base led to the formation of pyridochromanes $\mathbf{5 a}-\mathbf{d}$. The presented procedure provides several advantageous features including domino reaction character, one-pot procedure, high selectivity, mild reaction conditions, the simplicity of operation, high atomeconomy, and good to high yields.

\section{Experimental}

\section{General information}

Reagents and solvents were purchased from various commercial sources and were used directly without any further purification unless otherwise stated. ${ }^{1} \mathrm{H}$ and ${ }^{13} \mathrm{C}$ NMR spectra were recorded at 300 and $75 \mathrm{MHz}$, respectively. Chemical shifts were reported in parts per million ( $\delta$ ) using TMS, and coupling constants were expressed in Hertz. Melting points were recorded using an electrothermal capillary melting point apparatus and were uncorrected. HRMS spectra were recorded using highresolution mass spectra and were recorded on Mass-ESIPOS(FT-ICR-Qe) spectrometer.

\section{General procedure for the synthesis of com- pounds $\mathbf{1 a - g}$}

In a $25 \mathrm{~mL}$ flask containing $3 \mathrm{~mL}$ ethanol, 3-formylchromone derivatives $(1 \mathrm{mmol})$ and hydrazine derivatives $(1 \mathrm{mmol})$ were added and the mixture stirred for three hours at room temperature. The formed precipitate was filtered and washed with ethanol. Yields: 75-92\%.

\section{General procedure for the synthesis of com- pounds $\mathbf{4 a - m}$}

To a $25 \mathrm{~mL}$ flask containing $3 \mathrm{ml}$ ethanol, $1 \mathrm{mmol}$ (arylhydrazono)methyl-4H-chromen-4-one derivatives (1a-g), $1.2 \mathrm{mmol}$ primary amines (2a-d), $1.2 \mathrm{mmol}$ malononitrile (3), and triethylamine amine (40 mmol \%) were added and the mixture was stirred at room temperature for 8-12 hours. The progression of the reaction was monitored by TLC (eluent ethyl acetate $/ n$-hexane $3: 1)$. After completion of the reaction, the yellow precipitate $(\mathbf{4 a}-\mathbf{m})$ was filtered and washed with water and ethanol. Yields: $65-80 \%$.

\section{General procedure for the synthesis of com- pounds 5a-d}

In a $25 \mathrm{~mL}$ flask containing $3 \mathrm{ml}$ ethanol, $1 \mathrm{mmol}$ (arylhydrazono)methyl-4H-chromen-4-one derivatives (1a,b), $1.2 \mathrm{mmol}$ amine derivatives or 4-chloroaniline $(\mathbf{2 a}-\mathbf{c})$, and $1.2 \mathrm{mmol}$ malononitrile (3) were added and the mixture was stirred at room temperature for 3-4 hours. The progress of the reaction was monitored by TLC (eluent ethyl acetate/ $n$-hexane $1: 2$ ). After completion of the reaction, the yellow precipitate (5a-d) was filtered and washed with water and ethanol. Yields: $20-40 \%$.

\section{Supporting Information}

\section{Supporting Information File 1}

Analytical and spectroscopic data.

[https://www.beilstein-journals.org/bjoc/content/

supplementary/1860-5397-15-85-S1.pdf]

\section{Acknowledgements}

Saeed Balalaie thanks the Alexander von Humboldt Foundation for the research fellowship. We thank the Iran National Science Foundation (INSF, Grant No 97020936) for financial support.

\section{ORCID ${ }^{\circledR}$ iDs}

Fatima Hamdan - https://orcid.org/0000-0003-3463-1591

\section{References}

1. Cabrele, C.; Reiser, O. J. Org. Chem. 2016, 81, 10109-10125. doi:10.1021/acs.joc.6b02034

2. Blass, B. ACS Med. Chem. Lett. 2012, 3, 616-617. doi:10.1021/ml300158j

3. Panda, S.; Roy, A.; Deka, S. J.; Trivedi, V.; Manna, D. ACS Med. Chem. Lett. 2016, 7, 1167-1172. doi:10.1021/acsmedchemlett.6b00359

4. Zhu, J.; Wang, Q.; Wang, M.-X., Eds. Multicomponent Reactions in Organic Synthesis; Wiley-VCH: Weinheim, Germany, 2015. doi:10.1002/9783527678174

5. Müller, T. J. J., Ed. Science of Synthesis, Multicomponent Reactions I; George Thieme Verlag: Stuttgart, Germany, 2014.

6. Müller, T. J. J., Ed. Science of Synthesis Multicomponent Reactions II; George Thieme Verlag: Stuttgart, Germany, 2014.

7. Tietze, L. F.; Brasche, G.; Gericke, K. M. Domino Reactions in Organic Synthesis; Wiley-VCH: Weinheim, Germany, 2006. doi:10.1002/9783527609925

8. Tietze, L. F., Ed. Domino Reactions: Concepts for Efficient Organic Synthesis; Wiley-VCH: Weinheim, Germany, 2014. doi:10.1002/9783527671304

9. Tietze, L. F. Chem. Rev. 1996, 96, 115-136. doi:10.1021/cr950027e

10. Khan, T. A.; Fornefeld, T.; Hübner, D.; Vana, P.; Tietze, L. F. Org. Lett. 2018, 20, 2007-2010. doi:10.1021/acs.orglett.8b00553

11. Gaspar, A.; Matos, M. J.; Garrido, J.; Uriarte, E.; Borges, F. Chem. Rev. 2014, 114, 4960-4992. doi:10.1021/cr400265z 
12. Pratap, R.; Ram, V. J. Chem. Rev. 2014, 114, 10476-10526. doi:10.1021/cr500075s

13. Keri, R. S.; Budagumpi, S.; Pai, R. K.; Balakrishna, R. G. Eur. J. Med. Chem. 2014, 78, 340-374. doi:10.1016/j.ejmech.2014.03.047

14. Shaabani, A.; Hooshmand, S. E. RSC Adv. 2016, 6, 58142-58159. doi:10.1039/c6ra11701e

15. Balalaie, S.; Esmaeilabadi, H.; Mehrparvar, S.; Rominger, F.; Hamdan, F.; Bijanzadeh, H. R. SynOpen 2018, 2, 1-5. doi:10.1055/s-0036-1591869

16. Balalaie, S.; Derakhshan-Panah, F.; Zolfigol, M. A.; Rominger, F. Synlett 2018, 29, 89-93. doi:10.1055/s-0036-1590906

17. Teimouri, M. B.; Akbari-Moghaddam, P.; Golbaghi, G. ACS Comb. Sci. 2011, 13, 659-666. doi:10.1021/co200125a

18. Michailidou, M.; Giannouli, V.; Kotsikoris, V.; Papadodima, O.; Kontogianni, G.; Kostakis, I. K.; Lougiakis, N.; Chatziioannou, A.; Kolisis, F. N.; Marakos, P.; Pouli, N.; Loutrari, H. Eur. J. Med. Chem. 2016, 121, 143-157. doi:10.1016/j.ejmech.2016.05.035

19. Matsuda, D.; Kobashi, Y.; Mikami, A.; Kawamura, M.; Shiozawa, F.; Kawabe, K.; Hamada, M.; Oda, K.; Nishimoto, S.; Kimura, K.; Miyoshi, M.; Takayama, N.; Kakinuma, H.; Ohtake, N. Bioorg. Med. Chem. Lett. 2016, 26, 3441-3446. doi:10.1016/j.bmcl.2016.06.050

20. de Mello, H.; Echevarria, A.; Bernardino, A. M.; Canto-Cavalheiro, M.; Leon, L. L. J. Med. Chem. 2004, 47, 5427-5432. doi:10.1021/jm0401006

21. Mousseau, J. J.; Fortier, A.; Charette, A. B. Org. Lett. 2010, 12, 516-519. doi:10.1021/ol902710f

22. Gunasekaran, P.; Perumal, S.; Menéndez, J. C.; Mancinelli, M.; Ranieri, S.; Mazzanti, A. J. Org. Chem. 2014, 79, 11039-11050. doi:10.1021/j0502047n

23. Witherington, J.; Bordas, V.; Gaiba, A.; Garton, N. S.; Naylor, A.; Rawlings, A. D.; Slingsby, B. P.; Smith, D. G.; Takle, A. K.; Ward, R. W. Bioorg. Med. Chem. Lett. 2003, 13, 3055-3057. doi:10.1016/s0960-894x(03)00645-0

24. Lee, S.; Park, S. B. Org. Lett. 2009, 11, 5214-5217. doi:10.1021/ol902147u

25. Straub, A.; Benet-Buckholz, J.; Fröde, R.; Kern, A.; Kohlsdorfer, C.; Schmitt, P.; Schwarz, T.; Siefert, H.-M.; Stasch, J.-P. Bioorg. Med. Chem. 2002, 10, 1711-1717. doi:10.1016/s0968-0896(02)00034-2

26. Kendre, D. B.; Toche, R. B.; Jachak, M. N. Tetrahedron 2007, 63, 11000-11004. doi:10.1016/j.tet.2007.08.052

27. Abet, V.; Nuñez, A.; Mendicuti, F.; Burgos, C.; Alvarez-Builla, J. J. Org. Chem. 2008, 73, 8800-8807. doi:10.1021/jo801549u

28. Beutner, G. L.; Kuethe, J. T.; Kim, M. M.; Yasuda, N. J. Org. Chem. 2009, 74, 789-794. doi:10.1021/jo802363q

29. Ghaedi, A.; Bardajee, G. R.; Mirshokrayi, A.; Mahdavi, M.; Shafiee, A.; Akbarzadeh, T. RSC Adv. 2015, 5, 89652-89658. doi:10.1039/c5ra16769h

30. Bogza, S. L.; Kobrakov, K. I.; Malienko, A. A.; Perepichka, I. F.; Sujkov, S. Y.; Bryce, M. R.; Lyubchik, S. B.; Batsanov, A. S.; Bogdan, N. M. Org. Biomol. Chem. 2005, 3, 932-940. doi:10.1039/b417002d

31. Galvez, J.; Castillo, J.-C.; Quiroga, J.; Rajzmann, M.; Rodriguez, J.; Coquerel, Y. Org. Lett. 2014, 16, 4126-4129. doi:10.1021/ol5018245

32. Pettus, L. H.; Wurz, R. P.; Xu, S.; Herberich, B.; Henkle, B.; Liu, Q.; McBride, H. J.; Mu, S.; Plant, M. H.; Saris, C. J. M.; Sherman, L.; Wong, L. M.; Chmait, S.; Lee, M. R.; Mohr, C.; Hsieh, F.; Tasker, A. S. J. Med. Chem. 2010, 53, 2973-2985. doi:10.1021/jm100095x
33. Kumar, N. R.; Poornachandra, Y.; Swaroop, D. K.; Dev, G. J.; Kumar, C. G.; Narsaiah, B. Bioorg. Med. Chem. Lett. 2016, 26, 5203-5206. doi:10.1016/j.bmcl.2016.09.062

34. Zimmerman, J. R.; Myers, B. J.; Bouhall, S.; McCarthy, A.; Johntony, O.; Manpadi, M. Tetrahedron Lett. 2014, 55, 936-940. doi:10.1016/j.tetlet.2013.12.057

35. Gunasekaran, P.; Indumathi, S.; Perumal, S. RSC Adv. 2013, 3, 8318-8325. doi:10.1039/c3ra00136a

36. Heller, S. T.; Natarajan, S. R. Org. Lett. 2007, 9, 4947-4950. doi:10.1021/ol701784w

37. Balalaie, S.; Mirzaie, S.; Nikbakht, A.; Hamdan, F.; Rominger, F.; Navari, R.; Bijanzadeh, H. R. Org. Lett. 2017, 19, 6124-6127. doi:10.1021/acs.orglett.7b02603

38. Balalaie, S.; Shamakli, M.; Nikbakht, A.; Alavijeh, N. S.; Rominger, F.; Rostamizadeh, S.; Bijanzadeh, H. R. Org. Biomol. Chem. 2017, 15, 5737-5742. doi:10.1039/c7ob01142c

39. Balalaie, S.; Ramezani Kejani, R.; Ghabraie, E.; Darvish, F.; Rominger, F.; Hamdan, F.; Bijanzadeh, H. R. J. Org. Chem. 2017, 82, 12141-12152. doi:10.1021/acs.joc.7b01855

40. Balalaie, S.; Vaezghaemi, A.; Zarezadeh, N.; Rominger, F.; Bijanzadeh, H. R. Synlett 2018, 29, 1095-1101. doi:10.1055/s-0036-1591531

41. Plaskon, A. S.; Grygorenko, O. O.; Ryabukhin, S. V. Tetrahedron 2012, 68, 2743-2757. doi:10.1016/j.tet.2012.01.077

42. Słomiak, K.; Łazarenkow, A.; Chęcińska, L.; Kusz, J.; Ochocki, J.; Nawrot-Modranka, J. Molecules 2018, 23, 2067. doi:10.3390/molecules23082067

43. Wang, G.; Chen, M.; Wang, J.; Peng, Y.; Li, L.; Xie, Z.; Deng, B.; Chen, S.; Li, W. Bioorg. Med. Chem. Lett. 2017, 27, 2957-2961. doi:10.1016/j.bmcl.2017.05.007

44. Shen, H.; Xie, Z. J. Am. Chem. Soc. 2010, 132, 11473-11480. doi:10.1021/ja101796k

\section{License and Terms}

This is an Open Access article under the terms of the Creative Commons Attribution License (http://creativecommons.org/licenses/by/4.0). Please note that the reuse, redistribution and reproduction in particular requires that the authors and source are credited.

The license is subject to the Beilstein Journal of Organic Chemistry terms and conditions: (https://www.beilstein-journals.org/bjoc)

The definitive version of this article is the electronic one which can be found at: $\underline{\text { doi: } 10.3762 / \text { bjoc. } 15.85}$ 